\title{
Myostatin expression during development and chronic stress in zebrafish (Danio rerio)
}

\author{
S Vianello, L Brazzoduro, L Dalla Valle, P Belvedere \\ and $\mathbf{L}$ Colombo \\ Department of Biology, University of Padova, via U. Bassi 58/b, 35131 Padova, Italy \\ (Requests for offprints should be addressed to S Vianello; Email: tatoo@mail.bio.unipd.it)
}

\begin{abstract}
Myostatin, a member of the transforming growth factor- $\beta$ superfamily, is a negative regulator of skeletal muscle mass in mammals. We have studied myostatin expression during embryonic and post-hatching development in zebrafish by semiquantitative RT-PCR. The transcript is present in just-fertilized eggs and declines at $8 \mathrm{~h}$ postfertilization (hpf), suggesting a maternal origin. A secondary rise occurs at $16 \mathrm{hpf}$, indicating the onset of embryonic transcription at the time of muscle cell differentiation. The level of myostatin mRNA decreases slightly at $24 \mathrm{hpf}$, when somitogenesis is almost concluded, and rises again at and after hatching, during the period of limited muscle hyperplastic growth that is typical of slow-growing, small fish. In the adult muscle, we found the highest expression of myostatin mRNA and protein, which were detectable by Northern and Western blot analyses respectively.
\end{abstract}

Although only the precursor protein form was revealed in the adult lateral muscle, we demonstrated that zebrafish myostatin is proteolytically processed and secreted in cultured cells, as is its mammalian counterpart. These results suggest that myostatin may play an important regulatory role during myogenesis and muscle growth in fish, as it does in mammals.

In chronically stressed fish, grown from 16 days postfertilization to adulthood in an overcrowded environment, we observed both depression of body growth and a diminished level of myostatin mRNA in the adult muscle, as compared with controls. We propose that chronic stunting in fish brings about a general depression of muscle protein synthesis which does not spare myostatin.

Journal of Endocrinology (2003) 176, 47-59

\section{Introduction}

Myostatin (GDF-8), a member of the transforming growth factor (TGF) $\beta$ superfamily, is a negative regulator of skeletal muscle mass. Its function was first suggested by McPherron et al. (1997), who generated myostatin knockout mice that were characterized by a widespread increase in skeletal muscle mass, with a two to three times increase in individual muscle weight, due to a combination of muscle cell hyperplasia and hypertrophy. Similarly, mutations of the myostatin gene in some breeds of 'double muscled' cattle, that presumably lead to inactive proteins, were also associated with muscle growth (Grobet et al. 1997, 1998, Kambadur et al. 1997, McPherron \& Lee 1997, Cappucio et al. 1998). Moreover, a hypermuscular mouse mutant (Cmpt) (Szabó et al. 1998) shows a mutation in the putative propeptide region of the myostatin gene, which possibly interferes with the proper protein folding, dimerization and secretion (Gray \& Mason 1990).

These data suggest that myostatin performs a key role in controlling muscle mass during development. In fact, in mouse embryos, myostatin is expressed very early during development and its expression appears to be restricted to the myotome compartment of developing somites (McPherron \& Lee 1997). Studies in cattle (Kambadur et al. 1997, Bass et al. 1999), pigs (Ji et al. 1998) and chickens (Kocamis et al. 1999) have reported a similar myostatin expression pattern that begins early during development and continues throughout embryonic life. Myostatin mRNA abundance coincides roughly with the period of primary and secondary fibre formation, showing a reduction at hatching/birth and postnatally that may reflect the reduction in mytogenic and myogenic events.

In adult animals, skeletal muscle myostatin expression has been reported in several vertebrate species (Grobet et al. 1997, Kambadur et al. 1997, McPherron \& Lee 1997, Gonzalez-Cadavid et al. 1998, Ji et al. 1998, Sharma et al. 1999, Ostbye et al. 2001, Rescan et al. 2001, Roberts \& Goetz 2001, Rodgers et al. 2001). Although myostatin is predominantly expressed in the skeletal muscle, some reports have shown its occurrence in the Purkinje fibres and cardiomyocytes of the sheep heart (Sharma et al. 1999), in porcine lactating mammary gland (Ji et al. 1998) and, more recently, in several tissues of tilapia (Rodgers 
et al. 2001), Atlantic salmon (Østbye et al. 2001), rainbow trout (Rescan et al. 2001) and in the brain and ovary of brook trout (Roberts \& Goetz 2001).

The role of myostatin in the adult, differentiated muscle has not yet been fully clarified. Several reports have shown that muscle atrophy, induced by muscle unloading (Carlson et al. 1999, Wehling et al. 2000), exposure to a microgravity environment (Lalani et al. 2000) or associated with a pathological condition (Gonzalez-Cadavid et al. 1998), is accompanied by increments in muscle myostatin mRNA expression, muscle myostatin content and serum myostatin-related protein concentration (GonzalezCadavid et al. 1998). The myostatin level returns to normal values after reloading (Wehling et al. 2000).

On the other hand, myostatin expression declines during the first phase of muscle regeneration, characterized by a proliferation of the satellite cells, and goes up again during the differentiation of newly formed fibres (Kirk et al. 2000, Mendler et al. 2000). Moreover, myostatin expression was significantly reduced in two strains of mice that undergo muscle degeneration coupled with extensive regeneration (models of muscle dystrophy) (Zhu et al. 2000). In vitro proliferating myoblasts produced low amounts of myostatin mRNA, which increased only upon the induction of differentiation (Mendler et al. 2000, Ma et al. 2001, Artaza et al. 2002). Taken together, these results suggest a role, or at least an involvement, of myostatin in adult muscle mass changes.

Although the role of myostatin has been better studied in mammalian species, the isolation of myostatin cDNAs in different fish species (McPherron \& Lee 1997, Østbye et al. 2001, Rescan et al. 2001, Roberts \& Goetz 2001, Rodgers \& Weber 2001, Rodgers et al. 2001) has shown a high level of conservation, even related to the mammalian and avian orthologues, especially in the bioactive domain, suggesting an equally well conserved biological function. In order to understand the role that myostatin may play in fish muscle development and growth, we have investigated the myostatin mRNA expression in zebrafish during embryonic and larval development and in the muscles of fish grown in an overcrowded environment.

\section{Materials and Methods}

\section{Animals and sample collection}

All procedures were performed in accordance with the Guidelines on the Handling and Training of Laboratory Animals by the Universities Federation for Animal Welfare (UFAW) and with the Italian animal welfare legislation (D.L. 116/92).

Zebrafish were maintained and bred in aquaria according to the Zebrafish Book (Westerfield 1995). In the case of fish grown under overcrowded conditions, three lots of 40 eggs each were initially maintained in $500 \mathrm{ml}$ water. At
16 days post-fertilization (dpf), each lot was subdivided into two groups of 20 fish. The OC (overcrowded culture conditions) subgroups were grown in $500 \mathrm{ml}$ water until $90 \mathrm{dpf}$, while the $\mathrm{N}$ (normal culture conditions) subgroups were raised in 31 water until $50 \mathrm{dpf}$, then in 201 water until 90 dpf. All subgroups had food available ad libitum.

Just-fertilized eggs, embryos at different stage of development (following the description of Kimmel et al. 1995), larvae (from hatching till $20 \mathrm{dpf}$ ) and adult muscle samples were immediately frozen in liquid nitrogen after collection, and stored at $-80{ }^{\circ} \mathrm{C}$ until use. Skeletal muscle tissues were collected from fish killed by decapitation after anaesthesia in $20 \%$ tricaine. For total mRNA extraction, samples (100 eggs or $100 \mathrm{mg}$ skeletal muscle pooled from two or more animals) were powdered in liquid nitrogen using pestle and mortar and the RNA was isolated with the RNAzol B method (Genenco, Florence, Italy). For whole mount in situ hybridization, embryos were fixed overnight in $4 \%$ paraformaldehyde in phosphate-buffered saline (PBS) at $4{ }^{\circ} \mathrm{C}$, and stored in methanol at $-20{ }^{\circ} \mathrm{C}$ until use. For Western blot analysis, tissue samples were immediately used for protein isolation.

\section{Reverse transcription-polymerase chain reaction (RT-PCR) analysis and Southern blotting}

To study the myostatin expression during zebrafish development, a total of between 0.25 and $2 \mu \mathrm{g}$ total RNA isolated from embryos $(0,8,16,24,48$ and $72 \mathrm{~h}$ post fertilization (hpf)), 16-dpf larvae (fry) and adult lateral skeletal muscle were subjected to cDNA synthesis and amplification using the SuperScript One-Step RT-PCR system (Life Technologies Italia s.r.l., Milan, Italy) and two primers (forward primer: 161-TGC ATG CCA TCA AGT CCC AAA TTC-184; reverse primer: 681-GTT AAT CTC GAT GCC TCG GTT GGT-658) based on the zebrafish myostatin cDNA sequence (accession number: AF019626, McPherron \& Lee 1997). The primers were designed to span the first putative intron in order to reveal any contaminating genomic DNA as a larger sized PCR fragment. The intron position was extrapolated from that of human (Gonzalez-Cadavid et al. 1998) and porcine (accession number: AJ237662) myostatins.

After optimising the RT-PCR conditions and adjusting the number of cycles to be in the linear range of amplification for each sample, we performed semiquantitative RT-PCR analysis in $25-\mu$ l reaction mixture containing $0.5 \mu \mathrm{g}$ total mRNA, 5 pmol of each primer, $1 \times$ reaction mix, and $0.5 \mu \mathrm{RT}$-Platinum Taq mix, under the following conditions: 1 cycle at $54{ }^{\circ} \mathrm{C}$ for $30 \mathrm{~min}$ and $95^{\circ} \mathrm{C}$ for $2 \mathrm{~min}$ (reverse transcription); 35 cycles at $95^{\circ} \mathrm{C}$ for $30 \mathrm{~s}, 61{ }^{\circ} \mathrm{C}$ for $30 \mathrm{~s}$, and $72{ }^{\circ} \mathrm{C}$ for $45 \mathrm{~s}$, and 1 cycle at $72{ }^{\circ} \mathrm{C}$ for $10 \mathrm{~min}$ (amplification). Blanks were carried out in the absence of template RNA.

In order to check the quality and quantity of the RNA utilized for the semi-quantitative analysis, the total RNA 
dilutions used for each myostatin amplification were run on agarose gel. The quantification of template $28 \mathrm{~S}$ ribosomal RNA and of the amplified products was carried out by measuring the relative intensity of the bands stained by ethidium bromide using the Quantity One quantitation software (Bio-Rad Laboratories s.r.l., Milan, Italy).

The identity of the amplified 521-bp fragment obtained from 72-hpf embryos, 16-dpf larvae and adult muscle was confirmed by sequencing with the ABI PRISM Dye Terminator Cycle Sequencing Core Kit (Applied Biosystems, Monza, Italy). Electrophoresis of sequencing reactions was completed in an ABI PRISM automated sequencer, model 377 , version $2 \cdot 1 \cdot 1$. For all the developmental stages examined, the identity of amplified products was confirmed by Southern blot analysis. An aliquot $(1 / 10)$ of all RT-PCR products was electrophoresed in $1.0 \%$ agarose gel, transferred onto a charged nylon membrane (Hybond N+; Amersham Pharmacia Biotech Italia, Milan Italy), baked at $80^{\circ} \mathrm{C}$ for $2 \mathrm{~h}$, pre-hybridized at $42{ }^{\circ} \mathrm{C}$ for $2 \mathrm{~h}$ in a buffer containing $5 \times$ SSC (standard saline citrate), $50 \%$ formamide, $0 \cdot 1 \% \mathrm{~N}$-lauroylsarcosine, $0.02 \%$ sodium dodecyl sulphate (SDS), $2 \%$ polyvinylpyrrolidone, and then hybridized overnight at $42{ }^{\circ} \mathrm{C}$ in fresh hybridization buffer. This contained a digoxigeninlabelled cDNA myostatin probe synthesized by PCR (Roche Diagnostics, Milan, Italy) utilizing the same primers used for the RT-PCR reactions and a plasmid containing the complete zebrafish myostatin cDNA as a template (kindly provided by Dr S Lee, Johns Hopkins University School of Medicine, Baltimore, MD, USA; EMBL: AF019626). After hybridization, the membrane was washed and detection was performed as described in the DIG System User's Guide for Filter Hybridization provided by Roche, using the NBT/BCIP colorimetric detection system.

\section{Rapid amplification of $c D N A$ ends (RACE)}

5'-RACE was carried out using the 5'-RACE System (GibcoBRL, Milan, Italy) following the manufacturer's instructions. Briefly, cDNA was synthesized by incubating, at $50{ }^{\circ} \mathrm{C}$ for $1 \mathrm{~h}, 2 \mu \mathrm{g}$ total RNA from adult zebrafish muscle or 48-hpf embryos in $25 \mu \mathrm{l}$ of the required reaction mix, containing 4 pmol of the first specific primer for zebrafish myostatin (212-GGA GCC TGC TTG AGT CGG AG-193; AF019626). Terminal transferase was then used to add a homopolymeric C-tail to the $3^{\prime}$-end of the first-strand cDNA purified with a GlassMAX DNA Isolation Spin Cartridge Purification kit (GibcoBRL). The tailed cDNA was amplified by PCR, using a second (nested) specific primer (179-TGG GAC TTG ATG GCA TGC AG-160) and the oligo dG-abridged anchor primer (5'-GGC CAC GCG TCG ACT AGT ACG GGI IGG GII GGG IIG-3'). The primary PCR product was then nested-amplified using a third specific primer (122-GAA CAC AGC TCG CTT TCC-105) and the abridged universal amplification primer (5'-GGC CAC GCG TCG ACT AGT AC-3'). The resultant amplified product was purified from the sliced gel band and directly sequenced.

\section{Northern blot analysis}

To study the myostatin expression in the adult skeletal muscle and possible differences in the myostatin expression level between zebrafish grown under normal or overcrowded conditions, we performed Northern blot analysis on total RNA extracted from lateral skeletal muscle. Because of the small size of the muscle in OC fish, Northern analysis was performed on pooled tissues from animals belonging to each of the three different $\mathrm{OC}$ or $\mathrm{N}$ subgroups, and repeated at least three times for each subgroup.

Northern analysis was carried out according to Sambrook et al. (1989). Fifteen or twenty micrograms total mRNA were run on $1 \%$ formaldehyde-agarose gel and transferred to a Hybond $\mathrm{N}+$ membrane (Amersham). The membrane was prehybridized in $5 \times \mathrm{SSC}, 50 \%$ formamide, $0 \cdot 1 \%$ N-lauroyl-sarcosine, $0 \cdot 02 \%$ SDS, $2 \%$ Blocking Reagent (Roche) and hybridized overnight at $68^{\circ} \mathrm{C}$ in the same solution containing $60 \mathrm{ng} / \mathrm{ml}$ digoxigenin-labelled myostatin riboprobes, prepared with the DIG RNA labelling kit (Roche) using as a template Dr Lee's plasmid with the complete zebrafish myostatin cDNA. The complete plasmid sequencing showed the presence of the $5^{\prime}$ - and $3^{\prime}$-untranslated terminal regions (UTRs) that were not included in the deposited sequence (AF019626).

A mixture of two antisense riboprobes was used, one covering a 846-base fragment of the zebrafish myostatin cDNA clone corresponding to 67 bases of the $5^{\prime}$-UTR before the ATG and the pro-region portion (bases 1-779) of the coding region and the second one covering a 353-base fragment of the zebrafish myostatin 3'-UTR corresponding to bases 1171-1523. Probes corresponding to the C-terminal region of myostatin were excluded in order to avoid any possible crossreactivity with other members of the TGF- $\beta$ superfamily. Membranes were washed in $2 \times$ SSC and $0.1 \%$ SDS twice for $15 \mathrm{~min}$ at room temperature, and in $0 \cdot 2 \times$ SSC and $0 \cdot 1 \%$ SDS twice for $15 \mathrm{~min}$ at $65{ }^{\circ} \mathrm{C}$. They were then incubated with the anti-DIG-AP (Roche) and the signal detected using the CPD-Star DIG Luminescent Detection Kit (Roche) according to the manufacturer's protocol. Bands were visualized by autoradiography. Uniformity of loading and RNA integrity were verified by methylene blue staining of total RNA transferred on the membrane before hybridization.

\section{In situ hybridization on whole-mount embryos}

Whole-mount in situ hybridization was performed in fixed zebrafish embryos at 11,12, 14, 18, 24 and $48 \mathrm{hpf}$, 
according to Thisse et al. (1993), using the following riboprobes labelled with digoxigenin (Roche): an 846base zebrafish myostatin antisense probe, identical to the longer probe used for Northern blot analysis; a mixture of two 353- and 415-base zebrafish myostatin antisense probes, the first one identical to the other probe used for Northern blot analysis, the second one corresponding to a part of the pro-region (bases 365-779) in the coding region. The corresponding sense riboprobes were used as negative controls. In some cases, a double-colour hybridization was performed by adding a zebrafish MyoD cDNA (kindly provided by Dr Francesco Argenton, University of Padova, Italy) antisense riboprobe labelled with fluorescein (Roche), as a marker of muscle cell lineage.

\section{Myostatin expression in cultured cells}

The cDNA coding for zebrafish myostatin was cloned into the CS2 ${ }^{+}$expression vector (Turner \& Weintraub 1994), under the control of the simian CMVIE94 enhancer/ promoter. 293T cells (kindly provided by Dr Stefano Piccolo, University of Padova, Italy), seeded at 30\% confluence, were cultured for $24 \mathrm{~h}$ in DMEM (SigmaAldrich s.r.l., Milan, Italy) supplemented with $10 \%$ fetal calf serum (FCS), $0.6 \mathrm{~g} / 1 \mathrm{~L}$-glutamine, $0.1 \mathrm{U} / \mathrm{ml}$ penicillin and $0.1 \mathrm{U} / \mathrm{ml}$ streptomycin, and transiently transfected by calcium phosphate precipitation, according to Gilman (1988), using 10,20 or $40 \mu \mathrm{g}$ of the plasmid $\mathrm{CS}^{+}{ }_{-}$ myostatin and $0.5 \mu \mathrm{g}$ of the plasmid RSV- $\beta \mathrm{Gal}$. The medium was changed $21 \mathrm{~h}$ later with fresh medium without FCS.

Forty-eight hours after transfection, the conditioned medium with added $10 \mu \mathrm{M}$ phenylmethylsulphonylfluoride (PMSF) was concentrated by centrifugation in a Centriplus YM 3 spin column (Millipore Corporation, Bedford, MA, USA). Cells were scraped from the dish in a lysis buffer (100 mM tricine, pH 7·8, 2 mM EDTA, 1\% Triton X-100, 15\% glycerol, and $1 \mathrm{mM}$ dithiothreitol (DTT)) and centrifuged at $12000 \mathrm{~g}$ for $5 \mathrm{~min}$. $\beta$-Dgalactosidase activity was determined in the supernatant, as described by Sambrook et al. (1989), to check for transfection efficiency. For successive analyses of cells transfected with different plasmid amounts, the same quantities of concentrated conditioned medium or lysed cell supernatant were used, after dilution to correct for transfection efficiency.

\section{Protein isolation}

Adult zebrafish muscle and liver (used as a negative control) were homogenized in a buffer containing $40 \mathrm{mM}$ $\mathrm{K}_{2} \mathrm{HPO}_{4}, 10 \mathrm{mM} \mathrm{KH} \mathrm{PO}_{4}, 1 \mathrm{mM}$ EDTA, $65 \mathrm{mM} \mathrm{KCl}$, $1 \mathrm{mM}$ DTT, $0.5 \mu \mathrm{g} / \mathrm{ml}$ leupeptin, $0.7 \mu \mathrm{g} / \mathrm{ml}$ pepstatin A, and $2 \mu \mathrm{g} / \mathrm{ml}$ aprotinin, and centrifuged at $1000 \mathrm{~g}$ for
10 min. Protein concentration in the supernatants was determined by the Bradford method (Protein Assay Kit, Bio-Rad Laboratories), using BSA as a standard.

\section{Antibody production and Western blot analysis}

To prepare an antiserum against zebrafish myostatin, a histidine-tagged myostatin fusion protein was expressed in bacteria using the pQE31 expression system (Qiagen, Milan, Italy). Briefly, the cDNA encoding the C-terminal region of zebrafish myostatin, spanning amino acids 267 to 374, was amplified by PCR, as a SacI fragment, and cloned into the pQE31 vector in frame with codons for 6 histidine residues at the $\mathrm{N}$-terminus. The resulting construct was transfected into M15[pREP4] Escherichia coli strain and the myostatin fusion protein was induced for $5 \mathrm{~h}$ by adding $1 \mathrm{mM}$ isopropyl-thio- $\beta$-galactoside (IPTG) to 11 bacterial culture at an optical density (OD) of $0 \cdot 7$ (600 nm).

Bacteria were then collected by centrifugation, resuspended and incubated for $1 \mathrm{~h}$ in $5 \mathrm{ml}$ lysis buffer $/ \mathrm{g}$ bacterial pellet (6 M guanidine hydrochloride, $100 \mathrm{mM}$ $\mathrm{NaH}_{2} \mathrm{PO}_{4}, \quad 10 \mathrm{mM}$ Tris- $\mathrm{HCl}, \mathrm{pH}$, and $10 \mathrm{mM}$ 2-mercaptoethanol). The lysate was centrifuged at $12000 \mathrm{~g}$ for $15 \mathrm{~min}$ and myostatin was purified from the supernatant using a nickel-chelated column. Eluate fractions containing myostatin were pooled and used to inject rabbits. All immunizations were carried out by Cymbus Biotechnology Limited (Chandler Ford, Hants, UK). The $\operatorname{IgG}$ fraction from immune serum was purified using the Protein-A Sepharose CL-4B column (Sigma-Aldrich), according to the low salt procedure (Lane 1988).

For antibody validation, the purified antibody was used in a Western blot analysis of protein from induced and non-induced bacteria, and of different quantities of purified recombinant zebrafish myostatin protein. Rabbit pre-immune serum was used as a control on induced bacteria.

The concentrated medium and the supernatant of lysed myostatin-transfected 293T cells, and protein extracted from zebrafish muscle and liver were analysed by Western blotting. Cells transfected with the $\mathrm{CS}^{+}$expression vector alone were used as a negative control. Proteins were separated on $12 \%$ sodium dodecyl sulphate-polyacrylamide gel, according to Laemmli (1970), and transferred onto PVDF membrane (Roche). The filters were blocked in $5 \%$ BSA prepared in TBS-T $(20 \mathrm{mM}$ Tris- $\mathrm{HCl}, \mathrm{pH} 7 \cdot 6$, $137 \mathrm{mM} \mathrm{NaCl}$ and $0 \cdot 1 \%$ Tween-20) and incubated for $1 \mathrm{~h}$ at room temperature with $1 / 1500$ dilution of the purified zebrafish myostatin antibody in TBS-T. Filters were then washed $(3 \times 5 \mathrm{~min} ; 1 \times 15 \mathrm{~min})$ with TBS-T buffer and further incubated for $1 \mathrm{~h}$ at room temperature with 1/30000 dilution of goat horseradish peroxidase (HRP)-conjugated anti-rabbit IgG antibody (Pierce, Milan, Italy) in TBS-T. Membranes were washed as 
mentioned above and HRP activity was detected using the SuperSignal Chemiluminescent kit (Pierce) according to the manufacturer's protocol. In the case of liver and muscle, the primary antibody washing was performed either as reported above or in the presence of $0.3 \mathrm{M} \mathrm{NaCl}$.

\section{Statistical analysis}

Data were expressed as means \pm S.E.M. The body weight differences between fish grown under overcrowded or normal conditions were analysed by the Student's $t$-test.

RT-PCR analysis was performed on the total RNA extracted from three different lots for each stage examined, and was repeated at least three times for each lot. Densitometric values of cDNA bands were expressed as myostatin/28S rRNA ratios, the latter being a better visual indicator of RNA integrity because it is more readily degraded than 18S rRNA (Ivell 1998, Thellin et al. 1999). Data were then transformed as percentages of the myostatin expression in adult muscle (equal to 100) and analysed by one-way ANOVA. Comparison among densitometric data measured at each age was performed by Bonferroni's test. The differences among groups were considered significant at $P<0 \cdot 05$.

\section{Results}

\section{Expression of myostatin during zebrafish development}

In situ hybridization analysis on whole-mount zebrafish embryos during $(11,12,14$, and $18 \mathrm{hpf}$ ) and after (24 and $48 \mathrm{hpf}$ somitogenesis, using an antisense riboprobe specific for zebrafish myostatin, failed to reveal any specific signal (data not shown). This is in contrast with the results obtained in mice, where myostatin expression was easily detectable in the myotome compartment during somitogenesis using the same technique (McPherron \& Lee 1997). In situ hybridization on whole-mount zebrafish embryos at 14, 18 and $24 \mathrm{hpf}$, using a riboprobe for $M y o D$, a marker of muscle cell lineage, gave the expected pattern of expression (Weinberg et al. 1996), showing that the negative result obtained with the myostatin riboprobe was not due to technical problems.

When a more amplificative technique was used, such as the semiquantitative RT-PCR on total mRNA extracted from embryos at different stages of development, we could detect the expression of myostatin messenger. Figure 1A shows a representative image of the temporal expression of the transcript. The developmental profile is reported in Fig. 1C, where the levels of myostatin mRNA expression at different stages are displayed as percentages relative to the expression in adult muscle. The myostatin transcript was detectable in just-fertilized eggs ( $0 \mathrm{hpf}$ ), and its signal intensity declined at $8 \mathrm{hpf}(75 \%$ epiboly), a pattern consistent with the transfer and degradation of maternally transcribed RNA. A secondary rise at $16 \mathrm{hpf}$ (14-somite stage), to a level similar to that found in just-fertilized eggs, indicates the onset of myostatin gene embryonic transcription. Myostatin mRNA concentration showed a nonsignificant decrement at $24 \mathrm{hpf}$, when somite formation is concluded, followed by an increase until hatching and $16 \mathrm{dpf}$, when similar levels were found. The adult muscle always showed the highest level of myostatin mRNA expression, compared with all the developmental stages examined.

The sequencing of the more abundant transcripts (72 hpf, $16 \mathrm{dpf}$, and adult muscle) and Southern blot analysis at all stages examined, using a probe specific for zebrafish myostatin (Fig. 1B), confirmed the identity of the amplified products. Moreover, the $5^{\prime}$-RACE analysis of the myostatin mRNA expressed in 48-hpf embryos and adult skeletal muscle revealed a unique transcription start site for both developmental stages, located at $-79 \mathrm{nt}$ from the first in-frame ATG (sequence deposited with the accession number AJ318758). The sequence of the amplified products was identical in both cases.

\section{Myostatin $m R N A$ expression in the adult zebrafish skeletal} muscle and in cultured cells

As shown by RT-PCR analysis, myostatin mRNA is well expressed in the adult zebrafish skeletal muscle, at a level that is detectable even using a less amplificative technique, such as Northern blotting: a unique $2 \cdot 8-\mathrm{kb}$ transcript was observed using $15 \mu \mathrm{g}$ adult zebrafish lateral muscle probed with an anti-sense RNA specific for zebrafish myostatin (Fig. 2). This is in accordance with previous reports on several mammalian species (McPherron \& Lee 1997, Gonzalez-Cadavid et al. 1998, Ji et al. 1998, Mendler et al. 2000) and on trout (Roberts \& Goetz 2001), while it is in contrast with results on another fish species, tilapia, where myostatin mRNA expression was not detectable in the adult skeletal muscle, even using polyadenylated RNA (Rodgers et al. 2001).

To characterize the myostatin protein and its expression in the zebrafish skeletal muscle, we generated a polyclonal, affinity-purified antibody against a recombinant, histidinetagged, zebrafish myostatin C-terminal region, expressed in $E$. coli and purified using a nickel-chelated column. As shown in Fig. $3 \mathrm{~A}$, the $\operatorname{IgG}$ fraction from rabbit immune serum detected a recombinant, histidine-tagged, $17 \mathrm{kDa}$ myostatin protein from a bacterial extract induced to express myostatin, but no myostatin protein in a control non-induced extract, proving that the antibody specifically recognizes the myostatin recombinant protein. Furthermore, pre-immune rabbit serum did not detect any specific signal in the induced extract. In the Western blot analysis of affinity-purified, recombinant myostatin protein, the antibody recognized the protein in a manner that was proportional to the loaded amount (Fig. 3A). We used 


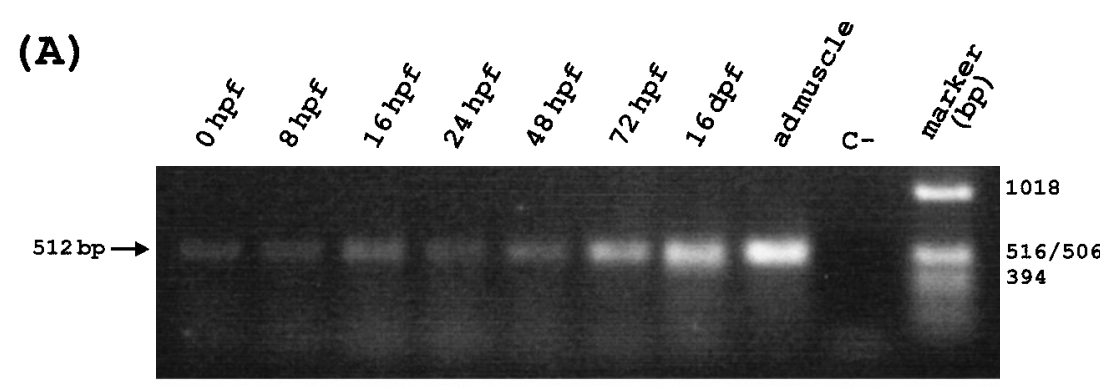

285

(B)

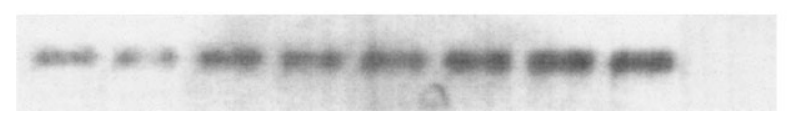

(C)

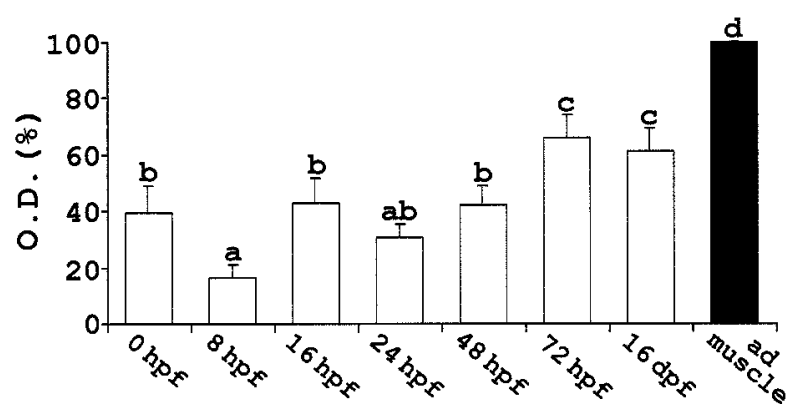

Figure 1 Stage-related expression of myostatin mRNA in just-fertilized eggs ( $0 \mathrm{~h}$ post-fertilization, hpf), during embryo development $(8,16,24$ and $48 \mathrm{hpf})$, at or just after hatching ( $72 \mathrm{hpf})$, at the larval stage at 16 days of life (dpf), and in the adult muscle (admuscle), as determined by semi-quantitative RT-PCR. (A) Representative images of ethidium bromide-stained gels. Total RNAs $(0.5 \mu \mathrm{g})$ from whole embryos and 16-dpf and adult zebrafish muscles, were reverse transcribed and amplified using primers specific for zebrafish myostatin. Negative control: C - , no template. An aliquot (10/25) of each amplified sample was size-separated by agarose gel electrophoresis and stained with ethidium bromide. The expected 512-bp amplified product is indicated by an arrow (top panel). The 28S rRNA (lower panel) is presented as an indicator of the quality and quantity of the total RNA used in the reaction. (B) Southern blot analysis of the amplified product, using a digoxigenin-labelled cDNA probe specific for zebrafish myostatin. The signal was detected using a colorimetric system, after 20-min reaction. (C) RT-PCR analysis performed in triplicate on three different lots of total RNA from each stage examined. The quantification of the amplified product and 28S rRNA was carried out by densitometry of the respective ethidium bromide-stained bands. Values were expressed as myostatin/28S rRNA optical density (O.D.) ratios, calculated as percentages of the myostatin expressed in the adult muscle (equal to 100), and subjected to statistical analysis. Different letters indicate a statistically significant difference $(P<0 \cdot 05$; Bonferroni's test).

this antibody to characterize myostatin expression in the adult zebrafish lateral muscle.

By Western blot analysis on the muscle homogenate, washing the primary antibody in the presence of $0.3 \mathrm{M}$ $\mathrm{NaCl}$, we detected a unique $40 \mathrm{kDa}$ immunoreactive band, that was not present in the liver homogenate used as a negative control (Fig. 3B). The size of this band is in accordance with the predicted mass of the unprocessed monomeric zebrafish myostatin precursor. Washing the primary antibody in the absence of $\mathrm{NaCl}$ (less stringent washing), we observed also a $15 \mathrm{kDa}$ band (Fig. 3C) that could correspond to the processed myostatin form, besides other faint bands. The same result was obtained (Fig. 3C) using the anti-human myostatin antibody $\mathrm{B}$ that is specific for a 16-amino acid peptide of the C-terminal region (kindly provided by Dr N F Gonzalez-Cadavid, Charles R Drew University, Los Angeles, CA, USA; Gonzalez-Cadavid et al. 1998). 


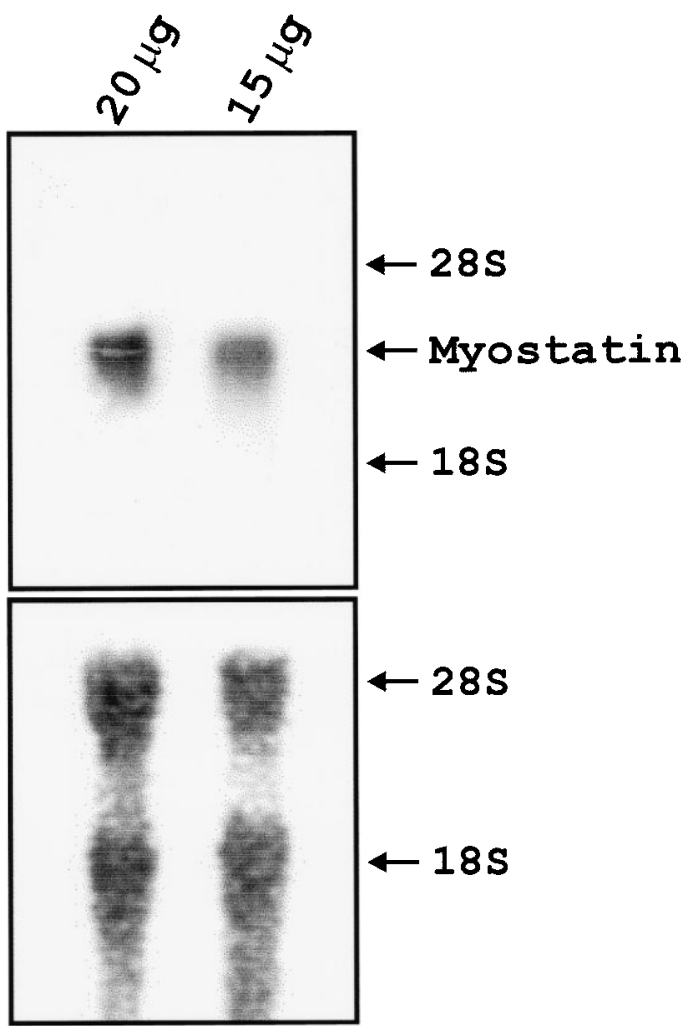

Figure 2 Expression of myostatin mRNA in adult zebrafish skeletal muscle revealed by Northern blot analysis of total muscle RNA (20 and $15 \mu \mathrm{g}$ ) (upper panel). The blot was hybridized with two digoxigenin-labelled antisense riboprobes, specific for zebrafish myostatin, and the signal was visualized with a luminescent detection system after 40 min of film exposure. Transcript size and position relative to $28 \mathrm{~S}$ and $18 \mathrm{~S}$ rRNAs are shown on the right of the upper panel. In the lower panel, methylene blue-stained $28 \mathrm{~S}$ and $18 \mathrm{~S}$ rRNA bands are shown, to confirm the integrity of the total RNA used.

To further study in vitro zebrafish myostatin processing and secretion, the $\mathrm{CS}^{+}$-myostatin plasmid (containing the zebrafish myostatin cDNA under the control of the cytomegalovirus (CMV) promoter) was transiently transfected into $293 \mathrm{~T}$ cells, and the lysed-cell supernatant and conditioned medium analysed by Western blotting $48 \mathrm{~h}$ after transfection. As shown in Fig. 4 (right panel), two specific bands of approximately 52 and $15 \mathrm{kDa}$ were detected in the conditioned medium of cells transfected with 10,20 or $40 \mu \mathrm{g}$ plasmid, whereas a unique $52 \mathrm{kDa}$ specific band was present in the lysed-cell supernatant (Fig. 4, left panel). The same bands were also recognized by the anti-human myostatin antibody B (data not shown). Other bands present in both the myostatin-transfected cells and control cells transfected with the $\mathrm{CS}^{+}$vector alone were considered not specific.

The 15 and $52 \mathrm{kDa}$ bands are in accordance with the values found in the literature for the myostatin protein expressed in mammalian cultured cells, corresponding to the processed mature monomeric form and the unprocessed monomeric form respectively (McPherron et al. 1997). Hence, like mouse myostatin (McPherron \& Lee 1997), zebrafish myostatin appears to be successfully proteolytically processed and secreted.

\section{Myostatin expression in zebrafish grown under overcrowded conditions}

Fish growth is markedly influenced by environmental and social factors (Wendelaar Bonga 1997). Zebrafish grown in an overcrowded (OC) environment from $16 \mathrm{dpf}$ (freeswimming larvae) showed, at $90 \mathrm{dpf}$ (adults), a delayed growth compared with fish raised under normal $(\mathrm{N})$ conditions (Fig. 5A). To examine whether myostatin expression was altered in overcrowded fish, we subjected the total RNA extracted from the lateral skeletal muscle to Northern blot analysis. Myostatin mRNA was markedly higher in normally grown fish than in overcrowded fish (Fig. 5B). The experiment was repeated on three separate lots of zebrafish, obtaining similar results.

\section{Discussion}

Embryonic muscle development has been extensively studied in zebrafish (van Raamnsdonk et al. 1978, Devoto et al. 1996), where slow and fast muscle fibres arise in this sequence from distinct populations of myoblasts.

In homeotherms, postnatal muscle development is mainly due to the hypertrophy of existing fibres (Goldspink 1972, Campion 1984). By contrast, in several fish species, hyperplastic recruitment of muscle fibres continues throughout much of the life cycle (Koumans \& Akster 1995, Johnston 1999). After hatching, two main phases of muscle hyperplastic growth can be distinguished. The first is observed in yolk-sac larvae, where myoblasts proliferate in the dorsal and ventral regions of the myotomes (Veggetti et al. 1990, Brooks \& Johnston 1993, Veggetti et al. 1993, Koumans et al. 1994, Rowlerson et al. 1995). The second phase occurs post-metamorphically in white muscle only and is typical of large, fast-growing species, being absent or greatly reduced in slow-growing, small fish (van Raamnsdonk et al. 1983, Weatherley \& Gill 1984, Weatherley et al. 1988, Veggetti et al. 1993), such as zebrafish, in which post-metamorphic muscle growth results solely from hypertrophy of existing fibres.

During mammalian and avian myogenesis, myostatin mRNA abundance peaks at the onset of secondary muscle fibre formation, reaches a minimum at birth and postnatally, and slightly increases again at adulthood (Ji et al. 1998, Kocamis et al. 1999, Oldham et al. 2001). In zebrafish, we have found that myostatin mRNA is already present in just-fertilized eggs $(0 \mathrm{hpf})$ and declines thereafter $(8 \mathrm{hpf})$, a pattern that is consistent with a maternal transfer of the transcript and its subsequent degradation. It 

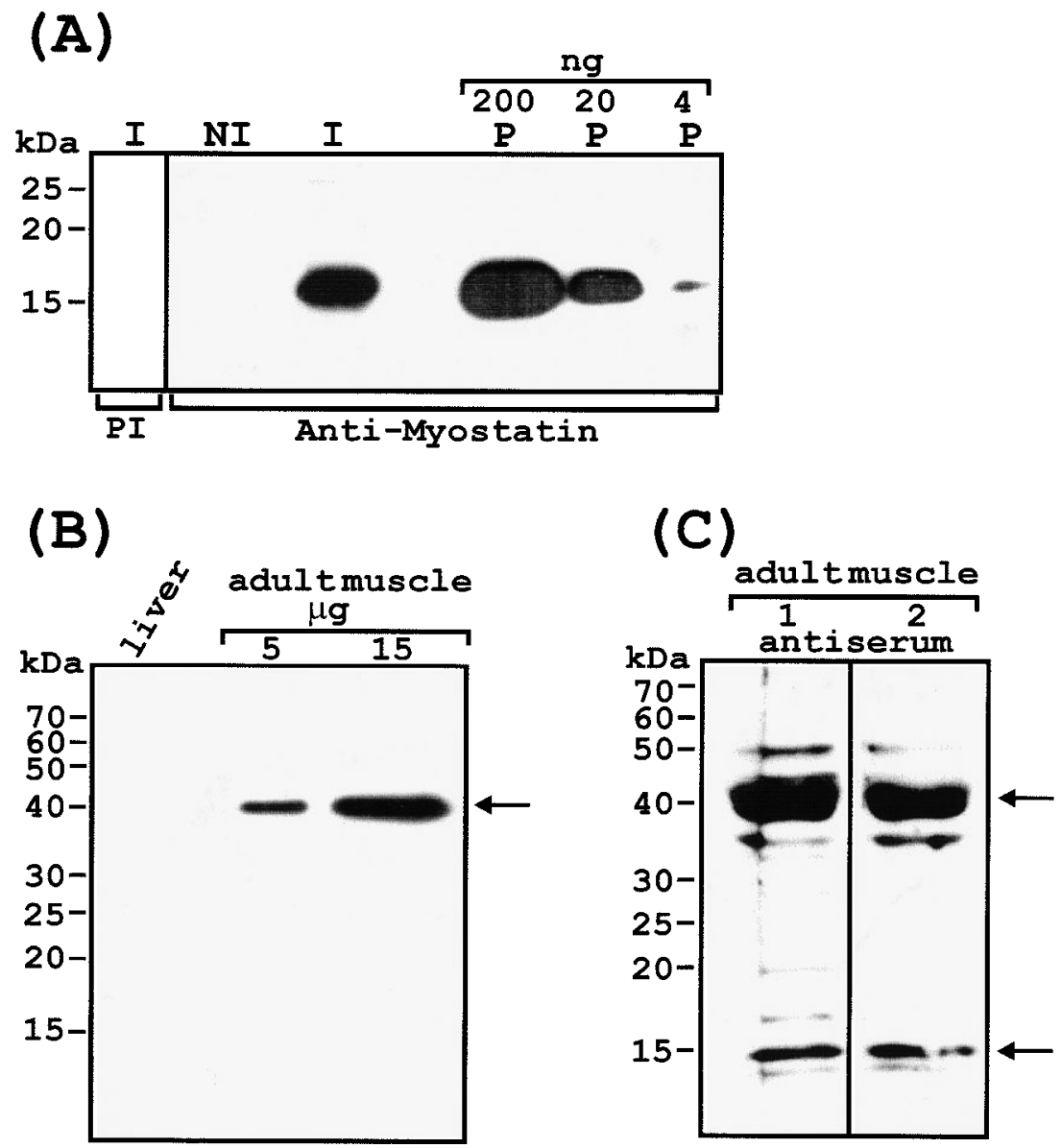

Figure 3 Expression of myostatin protein in adult zebrafish skeletal muscle revealed by Western blot analysis using a polyclonal antibody against a recombinant, polyhistidinetagged carboxy-terminal domain of zebrafish myostatin protein. (A) Antibody validation. Protein extracts from non-induced ( $\mathrm{NI}$ ) and induced (I) bacteria (carrying the expression plasmid containing the recombinant, histidine-tagged myostatin), and decreasing amounts of affinity-purified myostatin recombinant protein $(\mathrm{P})$ were electrophoresed on $12 \%$ polyacrylamide gel, blotted and probed with rabbit pre-immune $(\mathrm{PI})$ serum or rabbit antiserum IgG fraction against zebrafish myostatin. Membrane was washed in the presence of $0.3 \mathrm{M} \mathrm{NaCl}$. (B and C) Tissue detection of myostatin protein. (B) Protein extracts from lateral muscle ( 5 and $15 \mu \mathrm{g}$ ) or liver $(15 \mu \mathrm{g})$, the latter used as a negative control, were electrophoresed on $12 \%$ polyacrylamide gel, blotted and probed with anti-zebrafish myostatin antibody. The signal was visualized with a luminescent detection system after 5-s exposure. The putative unprocessed myostatin protein (arrow) and molecular mass markers (left) are shown. (C) Protein extracts from lateral muscle $(15 \mu \mathrm{g})$ were treated as before and probed with either anti-human myostatin antibody B (1) or anti-zebrafish myostatin antibody (2). Membranes were washed in the absence of $\mathrm{NaCl}$. The signal was visualized after 15-s exposure. The arrows indicate the putative unprocessed (upper arrow) and processed (lower arrow) forms of zebrafish myostatin.

has been shown, in several animal species, that maternally inherited mRNAs and proteins are used to program the earliest stages of development, but are degraded by the mid-blastula transition, allowing genetic control of development to pass to zygotically synthesized transcripts (Pendersen 1998). Maternal myostatin mRNA may be either directly transcribed by maturing or pre-ovulatory oocytes or transferred from granulosa cells into the oocytes (Patino \& Kagawa 1999).
Two forms of myostatin mRNA, with $92 \%$ identity at the nucleotide level, were isolated in the ovary of brook trout, where one form is predominantly expressed during ovulation (Roberts \& Goetz 2001). Two isoforms were also identified in both the rainbow trout, in which myostatin II is expressed only in muscle and brain, while myostatin I is present ubiquitously (Rescan et al. 2001), and the Atlantic salmon, whose two myostatins occur in multiple tissues (Østbye et al. 2001). 


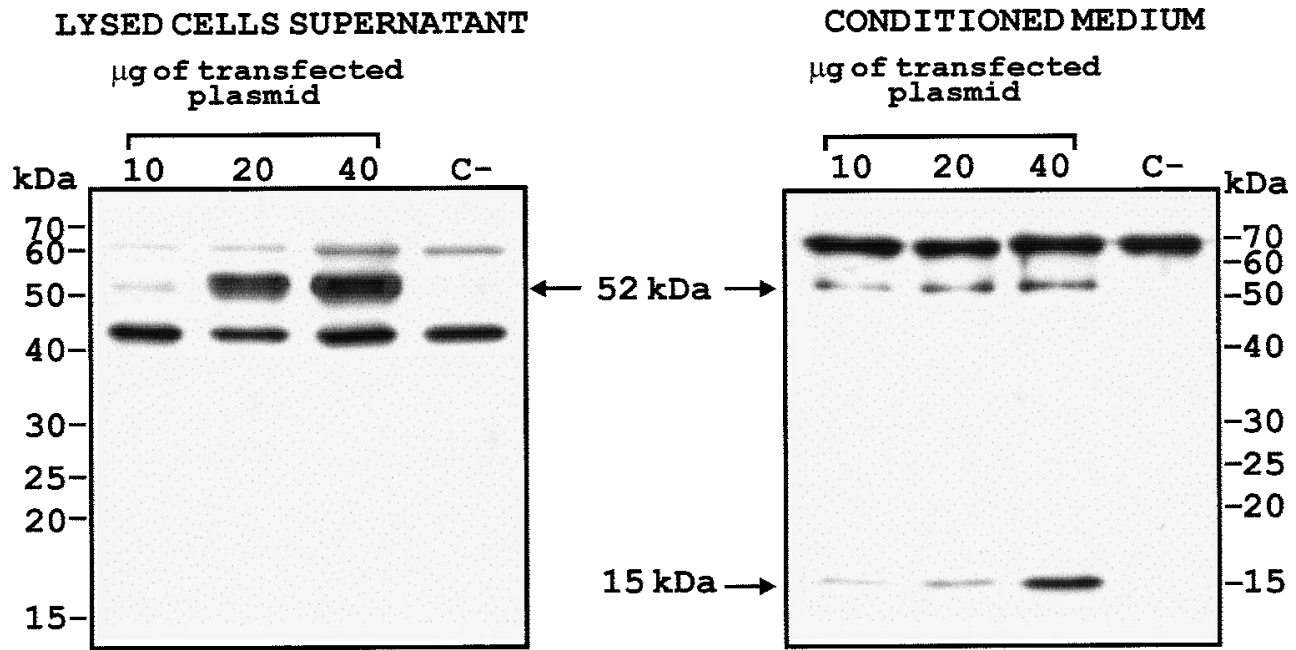

Figure 4 Secretion and processing of zebrafish myostatin in 293T transiently transfected cells, revealed by Western blotting using an antibody against zebrafish C-terminal myostatin domain. Cells were transfected with 10,20 or $40 \mu \mathrm{g}$ of the $\mathrm{CS}^{+}$-myostatin plasmid or with $40 \mu \mathrm{g}$ of the $\mathrm{CS}^{+}$vector alone $(\mathrm{C}-)$. Forty-eight hours after transfection, the lysed cells supernatant (left panel) and the concentrated conditioned medium (right panel) were electrophoresed on $12 \%$ polyacrylamide gel, blotted and probed with rabbit anti-myostatin IgG fraction. The signal was visualized with a luminescent detection system after 5 -s exposure. Expressed myostatin precursor $(52 \mathrm{kDa})$ and mature protein $(15 \mathrm{kDa})$, and molecular mass markers are indicated.

As the identity of myostatin mRNA in zebrafish eggs was verified by Southern blot analysis at low-stringency hybridization and washing temperature $\left(42^{\circ} \mathrm{C}\right)$, we might have failed to discriminate between very similar isoforms. For this reason, we cannot exclude the possibility that myostatin mRNA in zebrafish eggs is a different isoform of the transcript found in the embryo, larva and adult fish. On the other hand, we have demonstrated that myostatin mRNA expressed in yolk-sac larvae (72 hpf) and freeswimming larvae (16 dpf) is identical to the adult muscle form. Moreover, the $5^{\prime}$-UTR of the transcript in 48 -hpf embryos is also identical to the adult one.

In general, myogenic transcription factor genes, such as MyoD, are expressed earlier then muscle-specific protein genes (MSP), consistent with their upstream, regulatory role (Xu et al. 2000). In zebrafish, the expression of $\mathrm{MyoD}$ during embryonic development starts at 7 to $7.5 \mathrm{hpf}$, prior to somite formation, and drops markedly at $24 \mathrm{hpf}$, when somitogenesis is completed (Weinberg et al. 1996). Our pattern of myostatin expression in zebrafish embryos was timed as expected with respect to $\mathrm{MyoD}$ expression. In fact, the level of embryonic myostatin mRNA rose between 8 and $16 \mathrm{hpf}$, after the onset of MyoD expression and muscle cell differentiation (Devoto et al. 1996, Bladgen et al. 2000), and declined only slightly at $24 \mathrm{hpf}$, when $\mathrm{MyoD}$ expression and somite formation were almost concluded (Stickney et al. 2000). Thereafter, myostatin mRNA concentration rose again until hatching and $16 \mathrm{dpf}$ and reached the highest value in the adult muscle.
Since in zebrafish, as in other small teleost fish, red and white muscle fibres are well differentiated at hatching and the single wave of hyperplastic muscle growth after hatching is limited to some distinct germinal zones (Veggetti et al. 1993, Koumans \& Akster 1995, Johnston 1999), the observed increase in myostatin mRNA content at these stages and, particularly, in adult fish is in keeping with the fact that, in mammals, myostatin negatively regulates skeletal muscle growth by inhibiting myoblast proliferation (Thomas et al. 2000, Taylor et al. 2001).

These data suggest a key regulatory role of myostatin during early muscle development in both fish and mammals. However, the level of myostatin expression during mammalian somitogenesis appears to be higher, because, contrary to mammals (McPherron et al. 1997), the transcript was not detectable in zebrafish by whole mount in situ hybridization up to $48 \mathrm{hpf}$. In developing tilapia, myostatin mRNA was first revealed by RT-PCR only after hatching (Rodgers et al. 2001), thus even later than in zebrafish.

As in mammals, myostatin mRNA was readily detectable in adult zebrafish skeletal muscle by Northern blot analysis. By contrast, myostatin mRNA levels in tilapia white skeletal muscle were too low to be shown by Northern blotting (Rodgers et al. 2001). The authors proposed that this result could reflect the type of fibres sampled, as a differential expression of myostatin among white and red fibres was noted in various fish species (Østbye et al. 2001, Rescan et al. 2001, Roberts \& Goetz 


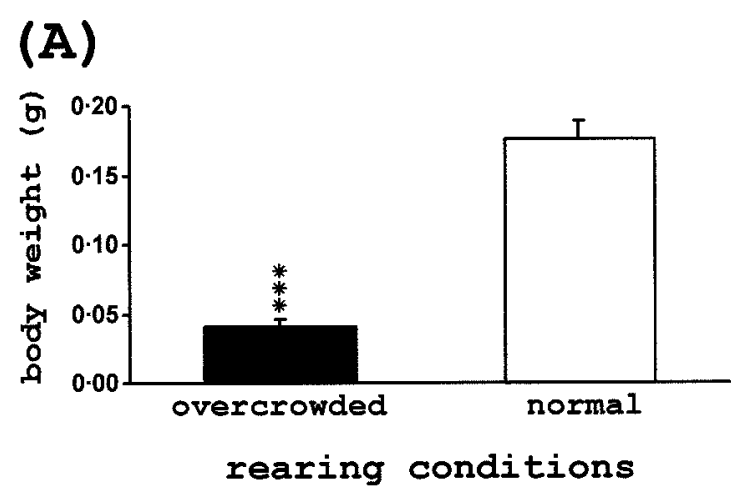

(B)

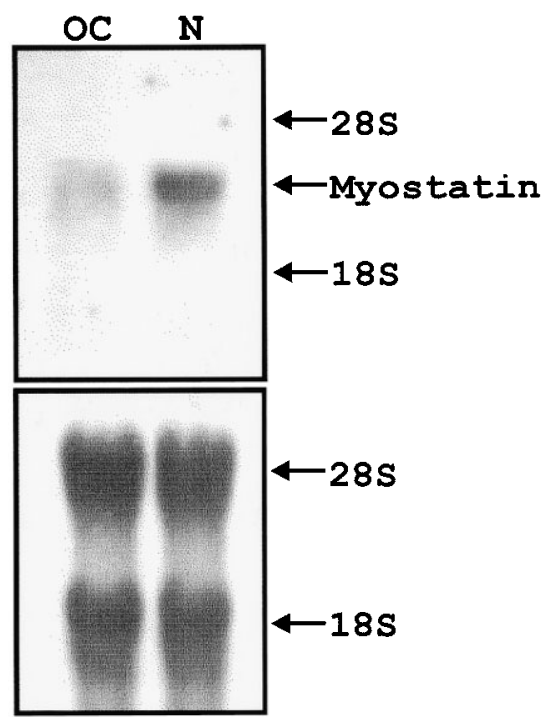

Figure 5 Myostatin expression in skeletal muscle of zebrafish grown under overcrowded (OC) or normal $(\mathrm{N})$ conditions. $(\mathrm{A})$ Body weight differences (means \pm S.E.M.) between zebrafish grown under overcrowded conditions since $16 \mathrm{dpf}$ or under normal conditions ( ${ }^{* *} P<0 \cdot 001 ; t$-test) are shown. (B) Representative Northern blot of total mRNA (20 $\mu \mathrm{g})$ from 90 -dpf zebrafish lateral muscle. The blot was hybridized with two digoxigenin-labelled antisense riboprobes, specific for zebrafish myostatin, and the signal was visualized with a chemiluminescent detection system after 1-h exposure. Transcript size and position relative to $28 \mathrm{~S}$ and $18 \mathrm{~S}$ rRNAs are shown on the right. In the lower panel, methylene blue-stained $28 \mathrm{~S}$ and $18 \mathrm{~S}$ rRNA bands are shown as indicators of equal RNA loading and integrity. The image is representative of three separate experiments conducted on three different subgroups of zebrafish grown under overcrowded or normal conditions.

2001). In our case, due to the small size of zebrafish, pools of whole (white and red) adult lateral muscle, from two or three different animals, were used for Northern blot analyses, thus averaging possible differences between fibre types.

Western blotting of adult zebrafish muscle extracts, using an antibody against the zebrafish myostatin
C-terminus, detected a $40 \mathrm{kDa}$ band, in accordance with the expected apparent molecular mass of the unprocessed myostatin precursor. A $15 \mathrm{kDa}$ fainter band, probably corresponding to the processed myostatin monomer, was revealed only after longer exposure and using a less stringent primary antibody washing. A similar result, confirming the specificity of our antibody, was obtained using the anti-human myostatin antibody B (GonzalezCadavid et al. 1998), that has been extensively validated by its ability to detect both the precursor and the processed mammalian protein (Lalani et al. 2000, Taylor et al. 2001). This antibody was raised against a 16-amino acid sequence within the C-terminal portion of the myostatin that is identical in human and zebrafish proteins. Using less stringent washing conditions a $37 \mathrm{kDa}$ unknown protein was detectable by our antibody, but at a lower level than the $15 \mathrm{kDa}$ band. This protein was only barely detectable by the Gonzalez-Cadavid's antibody, inferring the possible signal aspecificity.

Although several authors found a different molecular mass for the processed myostatin in mammalian muscle extract, ranging between 26 and $30 \mathrm{kDa}$ (GonzalezCadavid et al. 1998, Sharma et al. 1999, Lalani et al. 2000, Sakuma et al. 2000, Thomas et al. 2000, Taylor et al. 2001) (with several $\mathrm{kDa}$ differences reported even for the same species by different authors, despite using the same antibody), a considerable debate remains open, since in some reports lower molecular masses have been found. This is the case for the rat, where an $18-19 \mathrm{kDa}$ molecular mass has been reported for the mature protein (Mendler et al. 2000). It is also the case for the mouse (Zimmers et al. 2002 ), where the authors found a $12.5 \mathrm{kDa}$ protein in Western blot analysis of the serum of the wild-type mice, but not in that of the GDF-8 null animals $\left(\mathrm{Mstn}^{-/-}\right)$. In C2C12 myoblast cells transfected or not with the myostatin cDNA (Ríos et al. 2001), a band of $12 \mathrm{kDa}$ was found using the Gonzalez-Cadavid's antibody B. Expressing the complete myostatin propeptide in mammalian, non-muscular cells lines, different authors found a 12.5 to $15 \mathrm{kDa}$ band (McPherron et al. 1997, Lee \& McPherron 2001, Rodgers et al. 2001), corresponding to the mature monomer, that under non-reducing conditions shows an electrophoretic mobility consistent with that of the corresponding dimer. These results, together with other similar findings obtained expressing the C-terminal mature myostatin region in E. coli or Drosophila cells (Lalani et al. 2000, Taylor et al. 2001), suggest that the 26-30 kDa band found in several muscle extracts could be a mature myostatin dimer that does not fully dissociate despite the denaturing and reducing conditions employed in the Western blot analyses.

In our experiments the $15 \mathrm{kDa}$ immunoreactive band we found in zebrafish muscle extracts, essentially consistent with the predicted molecular mass of the mature zebrafish myostatin monomer, was also detected in mammalian $293 \mathrm{~T}$ cells, transiently transfected with the 
full-length zebrafish myostatin cDNA, but not in the negative control transfected cells.

In particular, Western blot analysis, using the antibody against the zebrafish myostatin C-terminus, demonstrated the occurrence of a $52 \mathrm{kDa}$ band, corresponding to the unprocessed precursor, in both the cell extract and the conditioned medium, and of a $15 \mathrm{kDa}$ signal in the medium, but not inside the cells. The presence of both precursor and processed forms was also observed in the medium of Chinese hamster ovary (CHO) cells stably transfected with mouse myostatin cDNA (McPherron et al. 1997). This confirms that zebrafish myostatin is processed and secreted in a similar manner as its mammalian orthologues, and that the precursor is cleaved in conjunction with or just after its secretion, as has been demonstrated for TGF- $\beta 1$ (Miyazono et al. 1991). It is also possible that some unprocessed myostatin in the medium is due to leakage from dead cells.

The apparent molecular masses of the unprocessed zebrafish myostatin found in transfected 293T cell cultures, is in accordance with the values reported in the literature for mammalian myostatin proteins expressed in cultured CHO mammalian cells (McPherron et al. 1997). Nevertheless, the mass of $52 \mathrm{kDa}$ for the unprocessed protein in cell culture is different from that of $40 \mathrm{kDa}$ estimated in zebrafish skeletal muscle. This difference in molecular weight might be due to some sort of posttranslational modification of the myostatin precursor, such as glycosylation and/or denaturation-resistant association with other proteins that might be prominent in mammalian but not in fish or other cells. In fact, expressing human myostatin in E. coli or Drosophila cells, Taylor and collaborators (2001) found a $45 \mathrm{kDa}$ immunoreactive band for the myostatin monomer precursor, whereas a higher, approximately $49-52 \mathrm{kDa}$ band, has previously been reported for the mammalian unprocessed myostatin expressed in mammalian muscle cells by several authors (Sharma et al. 1999, Lalani et al. 2000, Thomas et al. 2000). In our Western analysis the Gonzalez-Cadavid's antibody revealed a weak $50 \mathrm{kDa}$ band in zebrafish muscle that was barely detectable by our antibody. This probably means that the above post-translational processing or binding is less important in fish (strong $40 \mathrm{kDa}$ band and weak $50 \mathrm{kDa}$ band) as compared with the results obtained by other authors in mammalian cells (strong $49-52 \mathrm{kDa}$ and no $40 \mathrm{kDa}$ band).

An inverse correlation between myostatin levels and muscle mass has been reported during muscle atrophy in mammals (Gonzalez-Cadavid et al. 1998, Lalani et al. 2000). Moreover, when rats were subjected to muscle thermal injury, a damage that provokes a sustained elevation of glucocorticoids, Lang and collaborators (2001) noticed an increase in the myostatin mRNA level in muscle, concomitantly with a reduction in the muscle protein content. Similarly, dexamethasone enhanced the transcriptional activity of myostatin gene promoter con- structs transfected into skeletal muscle cells in culture (Ma et al. 2001).

In the experiment in which zebrafish were raised from 16 up to $90 \mathrm{dpf}$ under stressful overcrowding conditions, we observed a marked depression of body growth, resulting in stunting of fish, as well as a reduction of muscle myostatin mRNA expression.

Although this result seems to be in contrast with some of the above findings in mammals, it is in agreement with the report by Rescan et al. (2001) showing that, in rainbow trout, myostatin II mRNA, predominantly expressed in slow-twitch fibres, dropped dramatically in wasting muscles during sexual maturation, while myostatin I mRNA, expressed equally in red and white fibres, remained unchanged. This indicates that the muscle wastage occurring in fish both during sexual maturation and the stunting of muscle mass due to overcrowding are not dependent upon the up-regulation of myostatin expression. Rather, in these cases, the quenching of myostatin mRNA levels seems to be correlated to persistent catabolic or scarcely anabolic states in fish muscles.

The lowering of myostatin mRNA in the muscles of crowded fish does not necessarily conflict with the facts that crowding is stressful to fish and that the stress-induced elevation of glucocorticoids may enhance myostatin transcription. Fish can adapt to overcrowding, and it was found that, in chronically overcrowded brown trout, plasma cortisol levels returned to normal after a few weeks while body growth was depressed (Pickering \& Stewart 1984).

We did not measure plasma cortisol in the crowded zebrafish because the operation is technically complicated but, if this species can also hormonally adapt to overcrowding, it is conceivable that both cortisol and its up-regulation of myostatin expression were transitory and that the subsequent adjustment towards retarded body growth brought about a general depression of muscle protein synthesis which did not spare myostatin.

Further investigation is needed to determine whether the lower content of myostatin mRNA observed during wasting of normally developed muscles caused by protein mobilization for gonadal development in rainbow trout and the delay of muscle growth under overcrowding conditions in zebrafish rely on common or different regulatory mechanisms.

\section{Acknowledgements}

We are grateful to Dr Nestor Gonzalez-Cadavid (Charles R Drew University, Los Angeles, CA, USA) for providing the anti-human myostatin antibody B; to Dr Se-Jin Lee (Johns Hopkins University, Baltimore, MD, USA) for providing a vector containing the zebrafish myostatin cDNA; to Dr Stefano Piccolo and Dr Francesco Argenton 
(University of Padova, Padova, Italy) for providing the 293T cell line and the zebrafish MyoD cDNA respectively.

This research was supported by grant no. 5C 117 from the Ministry of Agriculture and Forestry Policies of Italy, in the purview of the Fifth Triennial Plan for Fisheries and Aquaculture in Marine and Brackish Waters; and by grants no. 99.00336.PF49 and no. 01.00734.PF49 from the National Research Council of Italy, project Biotechnology.

\section{References}

Artaza JN, Bhasin S, Mallidis C, Taylor W, Ma K \& Gonzalez-Cadavid NF 2002 Endogenous expression and localization of myostatin and its relation to myosin heavy chain distribution in C2C12 skeletal muscle cells. Journal of Cellular Physiology 184 356-363.

Bass J, Oldham J, Sharma M \& Kambadur R 1999 Growth factors controlling muscle development. Domestic Animal Endocrinology 17 191-197.

Bladgen CS, Currie PD, Ingham PW \& Hughes SM 2000 Notochord induction of zebrafish slow muscle mediated by Sonic hedgehog. Genes and Development 11 2163-2175.

Brooks S \& Johnston IA 1993 Influence of development and rearing temperature on the distribution, ultrastructure and myosin sub-unit composition of myotomal muscle fibre types in the plaice Pleuronectes platessa. Marine Biology 117 501-513.

Campion DR 1984 The muscle satellite cells; a review. International Review of Cytology 87 225-251.

Cappucio I, Marchitelli C, Seracchioli A, Nardone A, Filippini F, Aimone-Marsan P \& Valentini A 1998 A G-T transversion introduces a stop codon at the $\mathrm{mh}$ locus in hypertrophic Marchigiana beef subjects. Animal Genetics 29 (Suppl 1) 51.

Carlson CJ, Booth FW \& Gordon SE 1999 Skeletal muscle myostatin mRNA expression is fiber-type specific and increases during hindlimb unloading. American Journal of Physiology - Regulatory Integrative and Comparative Physiology 277 R601-R606.

Devoto SH, Melançon E, Eisen JS \& Westerfield M 1996 Identification of separate slow and fast muscle precursor cells in vivo, prior to somite formation. Development 122 3371-3380.

Gilman M 1988 Transfection of DNA into eukaryotic cells. In Current Protocols in Molecular Biology, pp 9.1.1-9.1.3. Eds FM Ausubel, R Brent, RE Kingston, DD More, TA Smith \& K Struhl. New York: John Wiley \& Sons.

Goldspink G 1972 Postembryonic growth and differentiation of striated muscle. In The Structure and Function of Muscle, edn 2, vol. 1, p 179. Ed. GH Bourne. New York: Academic Press.

Gonzalez-Cadavid NF, Taylor WE, Yarasheski K, Sinha-Hikim I, Ma K, Ezzat S, Shen R, Lalani R, Asa S, Mamita M, Nair G, Arver S \& Bhasin S 1998 Organization of the human myostatin gene and expression in healthy men and HIV-infected men with muscle wasting. PNAS 95 14938-14943.

Gray AM \& Mason AJ 1990 Requirement for activin A and transforming growth factor- $\beta 1$ pro-regions in homodimer assembly. Science 247 1328-1330.

Grobet L, Martin LJR, Poncelet D, Pirottin D, Browers B, Riquet J, Schoeberlein A, Dunner S, Ménissier F, Massabanda J, Fries R, Hanset R \& Georges M 1997 A deletion in the bovine myostatin gene causes the double-muscled phenotype in cattle. Nature Genetics 17 71-74.

Grobet L, Poncelet D, Royo LJ, Brouwers B, Pirottin D, Michaux C, Ménissier F, Zanotti M, Dunner S \& Georges M 1998 Molecular definition of an allelic series of mutations disrupting the myostatin function and causing double-muscling in cattle. Mammalian Genome $9210-213$.
Ivell R 1998 A question of faith - or the philosophy of RNA controls. Journal of Endocrinology 159 197-200.

Ji S, Losinski RL, Cornelius SG, Frank GR, Willis GM, Gerrard DE, Depreux FFS \& Spurlock ME 1998 Myostatin expression in porcine tissues: tissue specificity and developmental and postnatal regulation. American Journal of Physiology - Regulatory Integrative and Comparative Physiology 275 R1265-R1273.

Johnston IA 1999 Muscle development and growth: potential implications for flesh quality in fish. Aquaculture 177 99-115.

Kambadur R, Sharma M, Smith TPL \& Bass JJ 1997 Mutations in myostatin (GDF-8) in double-muscled Belgian Blue and Piedmontese cattle. Genome Research 7 910-915.

Kimmel CB, Ballard WW, Kimmel SR, Ullmann B \& Schilling TF 1995 Stages of embryonic development of the zebrafish. Developmental Dynamics 203 253-310.

Kirk S, Oldham J, Kambadur R, Sharma M, Dobbie P \& Bass J 2000 Myostatin regulation during skeletal muscle regeneration. Journal of Cellular Physiology 184 356-363.

Kocamis H, Kirkpatrick-Keller DC, Richter J \& Killefer J 1999 The ontogeny of myostatin, follistatin and activin-B mRNA expression during chicken embryonic development. Growth, Development and Aging 63 143-150.

Koumans JTM \& Akster HA 1995 Myogenic cells in development and growth of fish. Comparative Biochemistry and Physiology Part A: Molecular and Integrative Physiology 110 3-20.

Koumans JTM, Akster HA, Witkam A \& Osse JWM 1994 Numbers of muscle nuclei and myosatellite cell nuclei in red and white axial muscle during growth of the carp (Cyprinus carpio L.). Journal of Fish Biology 44 391-408.

Laemmli UK 1970 Cleavage of structural proteins during the assembly of the head of bacteriophage T4. Nature 227 680-685.

Lalani R, Bhasin S, Byhower F, Tarnuzzer R, Grant M, Shen R, Asa S, Ezzat S \& Gonzalez-Cadavid NF 2000 Myostatin and insulin-like growth factor-I and -II expression in the muscle of rats exposed to the microgravity environment of the NeroLab space shuttle flight. Journal of Endocrinology 167 417-428.

Lane D 1988 Storing and purifying antibodies. In Antibodies. A Laboratory Manual, p 310. Ed. I Harlow. Cold Spring Harbor, New York, USA: Cold Spring Harbor Laboratories Press.

Lang CH, Silvis C, Nystrom G \& Frost RA 2001 Regulation of myostatin by glucocorticoids after thermal injury. FASEB Journal 15 1807-1809.

Lee S-J \& McPherron AC 2001 Regulation of myostatin activity and muscle growth. PNAS 98 9306-9311.

Ma K, Mallidis C, Artaza J, Taylor W, Gonzalez-Cadavid N \& Bhasin S 2001 Characterization of $5^{\prime}$-regulatory region of human myostatin gene: regulation by dexamethasone in vitro. American Journal of Physiology - Endocrinology and Metabolism 281 E1128-E1136.

McPherron AC \& Lee S-J 1997 Double muscling in cattle due to mutations in the myostatin gene. PNAS 94 12457-12461.

McPherron AC, Lawler AM \& Lee S-J 1997 Regulation of skeletal muscle mass in mice by a new TGF- $\beta$ superfamily member. Nature 387 83-90.

Mendler L, Zádor E, Ver Heyen M, Dux L \& Wuytack F 2000 Myostatin levels in regenerating rat skeletal muscles and in myogenic cell cultures. Journal of Muscle Research and Cell Motility 21 551-563.

Miyazono K, Olofsson A, Colosetti P \& Heldin C-H 1991 A role of the latent TGF- $\beta 1$-binding protein in the assembly and secretion of TGF- $\beta 1$. EMBO Journal 10 1091-1101.

Oldham JM, Martyn JAK, Sharma M, Jeanplong F, Kambadur R \& Bass JJ 2001 Molecular expression of myostatin and MyoD is greater in double-muscled than normal-muscled cattle fetuses. American Journal of Physiology - Regulatory, Integrative and Comparative Physiology 280 R1488-R1493. 
Østbye T-K, Galloway TF, Nielsen C, Gabestad I, Bardal T \& Andersen Ø 2001 The two myostatin genes of Atlantic salmon (Salmo salar) are expressed in a variety of tissues. European Journal of Biochemistry 268 1-10.

Patino Ri \& Kagawa H 1999 Regulation of gap junctions and oocyte maturational competence by gonadotropin and insulin-like growth factor-I in ovarian follicles of red seabream. General and Comparative Endocrinology 115 454-462.

Pendersen RA 1998 Early mammalian embryogenesis. In The Physiology of Reproduction, vol 1, pp 187-230. Eds E Knobil, JD Neill, LL Ewing, GS Greenwald, CL Markeret, DW Pfaff. New York: Raven Press.

Pickering AD \& Stewart A 1984 Acclimation of the interrenal tissue of the brown trout, Salmo trutta L., to chronic crowding stress. Journal of Fish Biology 24 731-740.

van Raamnsdonk W, Pool CW \& te Kronnie G 1978 Differentiation of muscle fiber types in the teleost Brachydanio rerio. Anatomy and Embryology 153 137-155.

van Ramnsdonk W, Mos W, Smit-Onel MJ, van der Laarse WJ \& Fehres R 1983 The development of the spinal motor column in relation to the myotomal muscle fibers in the zebrafish (Brachydanio rerio). Anatomy and Embryology 167 125-139.

Rescan P-Y, Jutel I \& Rallière C 2001 Two myostatin genes are differentially expressed in myotomal muscles of the trout (Oncorhynchus mykiss). Journal of Experimental Biology 204 3523-3529.

Ríos R, Carneiro I, Arce VM \& Devesa J 2001 Myostatin regulates cell survival during C2C12 myogenesis. Biochemical and Biophysical Research Communications 280 561-566.

Roberts SB \& Goetz FW 2001 Differential skeletal muscle expression of myostatin across teleost species, and the isolation of multiple myostatin isoforms. FEBS Letters 491 212-216.

Rodgers BD \& Weber GM 2001 Sequence conservation among fish myostatin orthologues and the characterization of two additional cDNA clones from Morone saxatilis and Morone americana. Comparative Biochemistry and Physiology Part B: Biochemistry and Molecular Biology 129 597-603.

Rodgers BD, Weber GM, Sullivan CV \& Levine MA 2001 Isolation and characterization of myostatin complementary deoxyribonucleic acid clones from two commercially important fish: Oreochromis mossambicus and Morone chrysops. Endocrinology 142 1412-1418.

Rowlerson A, Mascarello F, Radaelli G \& Veggetti A 1995 Differentiation and growth of muscle in the fish Sparus aurata (L): II. Hyperplastic and hypertrophic growth of lateral muscle from hatching to adult. Journal of Muscle Research and Cell Motility 16 223-236.

Sakuma K, Watanabe K, Sano M, Uramoto I \& Totsuka T 2000 Differential adaptation of growth and differentiation factor $8 /$ myostatin, fibroblast growth factor 6 and leukaemia inhibitory factor in overloaded, regenerating and denervated rat muscles. Biochimica et Biophysica Acta 1497 77-88.

Sambrook J, Fritsh EF \& Maniatis T 1989 Molecular Cloning. A Laboratory Manual. Cold Spring Harbor, New York, USA: Cold Spring Harbor Laboratories Press.

Sharma M, Kambadur R, Matthews KG, Somers WG, Devlin GP, Conaglen JV, Fowke PJ \& Bass JJ 1999 Myostatin, a transforming growth factor- $\beta$ superfamily member, is expressed in heart muscle and is upregulated in cardiomyocytes after infarct. Journal of Cellular Physiology 180 1-9.

Stickney HL, Barresi MJF \& Devoto SH 2000 Somite development in zebrafish. Developmental Dynamics 219 287-303.

Szabó G, Dallmann G, Müller G, Patthy L, Soller M \& Varga L 1998 A deletion in the myostatin gene causes the compact (Cmpt) hypermuscular mutation in mice. Mammalian Genome 9 671-672.
Taylor WE, Bhasin S, Artaza J, Byhower F, Azam M, Willard DH, Kull FC \& Gonzalez-Cadavid N 2001 Myostatin inhibits cell proliferation and protein synthesis in $\mathrm{C}(2) \mathrm{C}(12)$ muscle cells. American Journal of Physiology - Endocrinology and Metabolism 280 E221-E228.

Thellin O, Zorzi W, Lakaye B, De Borman B, Coumans B, Hennen G, Grisar T, Igout A \& Heinen E 1999 Housekeeping genes as internal standards: use and limits. Journal of Biotechnology $\mathbf{7 5}$ 291-295.

Thisse TB, Schilling TF \& Postlethwait JH 1993 Structure of the zebrafish snaill gene and its expression in wild-type, spadetail and no tail mutant embryos. Development 119 1203-1215.

Thomas M, Langley B, Berry C, Sharma M, Kirk S, Bass J \& Kambadur R 2000 Myostatin, a negative regulator of muscle growth, functions by inhibiting myoblast proliferation. Journal of Biological Chemistry 275 40235-40243.

Turner DL \& Weintraub H 1994 Expression of achaete-scute homolog 3 in Xenopus embryos converts ectodermal cells to neural fate. Genes and Development 8 1434-1447.

Veggetti A, Mascarello F, Scapolo PA \& Rowlerson A 1990 Hyperplastic and hypertrophic growth of lateral muscle in Dicentrarchus labrax (L.). An ultrastructural and morphometric study. Anatomy and Embryology 182 1-10.

Veggetti A, Mascarello F, Scapolo PA, Rowlerson A \& Candia Carnevali MD 1993 Muscle growth and myosin isoform transitions during development of a small teleost fish, Poecilia reticulata (Peters) (Atheriniformes, Poeciliidae): a histochemical, immunohistochemical, ultrastructural and morphometric study. Anatomy and Embryology 187 353-361.

Weatherley AH \& Gill HS 1984 Growth dynamics of white myotomal muscle fibres in the bluntnose minnow, Pimephales notatus Rafinesque, and comparison with rainbow trout, Salmo gairdneri Richardson. Journal of Fish Biology 25 13-24.

Weatherley AH, Gill HS \& Lobo AF 1988 Recruitment and maximal diameter of axial muscle fibres in teleosts and their relationship to somatic growth and ultimate size. Journal of Fish Biology 33 851-859.

Wehling M, Cai B \& Tidball JG 2000 Modulation of myostatin expression during modified muscle use. FASEB Journal 14 103-110.

Weinberg ES, Allende ML, Kelly CS, Abdelhamid A, Murakami T, Andermann P, Doerre OG, Grunwald DJ \& Riggleman B 1996 Developmental regulation of zebrafish $M y o D$ in wild-type, no tail and spadetail embryos. Development 122 271-280.

Wendelaar Bonga SE 1997 The stress response in fish. Physiological Reviews 77 591-625.

Westerfield M 1995 The Zebrafish Book: A Guide for the Laboratory Use of Zebrafish (Danio rerio), edn 3. Eugene, OR, USA: University of Oregon Press.

Xu Y, He J, Wang X, Lim TM \& Gong Z 2000 Asynchronous activation of 10 muscle-specific protein (MSP) genes during zebrafish somitogenesis. Developmental Dynamics 219 201-215.

Zhu X, Hadhazy M, Wehling M, Tidball JG \& McNally EM 2000 Dominant negative myostatin produces hypertrophy without hyperplasia in muscle. FEBS Letters 474 71-75.

Zimmers TA, Davies MV, Koniaris LG, Haynes P, Esquela AF, Tomkinson KN, McPherron AC, Wolfman NM \& Lee S-J 2002 Induction of cachexia in mice by systemically administered myostatin. Science 296 1486-1488.

Received 16 July 2002

Accepted 18 September 2002 